\title{
Actions for small water retention undertaken in Poland
}

\section{Zbigniew KOWALEWSKI}

Institute for Land Reclamation and Grassland Farming, Falenty, ul. Hrabska 3, 05-090 Raszyn, Poland, e-mail: z.kowalewski@imuz.edu.pl

\begin{abstract}
An increase of water retention in the programmes of small retention in the country to the year 2015 is estimated at 1141 million $\mathrm{m}^{3}$. It means annual mean increase of retention capacity by c. 60 million $\mathrm{m}^{3}$. Accomplishment of relevant actions in the years 1997-2007 allowed collecting 57 million $\mathrm{m}^{3}$ in lakes, c. 56 million $\mathrm{m}^{3}$ in artificial reservoirs, 18.5 million $\mathrm{m}^{3}$ in fishponds, c. 10.5 million $\mathrm{m}^{3}$ with the channel retention and over 2 million $\mathrm{m}^{3}$ in other investments. It makes total increase of water retention by 142 million $\mathrm{m}^{3}$ which is $12.4 \%$ of target retention and the mean annual increment of c. 13 million $\mathrm{m}^{3}$.

The paper presents volumes of retained water, sources and structure of financing, mean unit costs of retention increments and the increase of retention capacity in particular voivodships (acc. to new administration division) in the years 1998-2007.
\end{abstract}

Key words: retention increment, small retention, unit costs, water reservoirs

\section{INTRODUCTION}

Since the beginning of the 1990th agriculture have encountered climate changes which manifested themselves by dry years, less snowy winters and rapid floods even in small rivers. It posed periodical problems in water management because Poland is a country of relatively small water resources and their variable spatial distribution. Actions were undertaken to slow down or hamper water outflow from natural and artificial running waters, to store waters in small reservoirs and terrain depressions and to increase the retention of water in soils and aquifers. In Poland such actions are termed "small retention" as opposed to water retention in large reservoirs for power production, flood control, drinking water intakes for large cities etc.

Basic data on small retention programmes in the country and on results of its implementation in the years 1997-2007 are given in this paper. 


\section{ASSUMPTIONS OF THE SMALL RETENTION PROGRAMME - VOIVODSHIP PROGRAMMES}

Development of small retention in the country started in the year 1995 as a result of the agreement between the ministries of agriculture and environment [Porozumienie..., 1996] which agreed on various common actions aimed at improving the availability of water resources. The programme had to be accomplished to the year 2015.

Each voivodship was obliged to elaborate the programme of small retention development which would consist in the construction, reconstruction and modernisation of water storage facilities of a maximum capacity of 5 million $\mathrm{m}^{3}$ (usually, however, not exceeding 1 million $\mathrm{m}^{3}$ ). Moreover, it was agreed that particular programmes should:

- facilitate the reduction of surface runoff through planting forests and midfield woods,

- stop degradation of the existing and start the construction of new reclamation facilities, particularly those intended for irrigation, water lifting and hampering rapid water outflow,

- consider the possibility of flood control,

- locate the objects in places appropriate for increasing the recharge of aquifers,

- consider the motions of local communities (communes, farmers),

- be agreed on with regional boards of water management.

Most of 49 programmes were prepared in 1996 with the consideration of the then administration division into voivodships. Programmes were mainly elaborated by voivodship boards of land reclamation and water facilities but also by construction design companies and scientific institutions associated with reclamation and water management,

Proposals presented by particular voivodships were quite variable as to the general concept of actions, various elements of small retention, detail of information, environmental impact, costs and the assessment of economic efficiency. Planned increase of the volume of retained water was mainly based on small reservoirs (ponds) where c. 860 million $\mathrm{m}^{3}$ had to be stored in 4789 reservoirs. Damming 620 lakes would increase water retention by 263 million $\mathrm{m}^{3}$ and water lifting in basic and detailed reclamation network would bring additional 18 million $\mathrm{m}^{3}$. Up to the year 2015 water storage within the programme of small retention was forecasted at c. 1141 million $\mathrm{m}^{3}$.

Large reservoirs $\left(>5\right.$ million $\left.\mathrm{m}^{3}\right)$ store c. 3396 million $\mathrm{m}^{3}$ in the country [Ochrona..., 2006]. So, planned increase of water storage capacity is c. $1 / 3$ of the present volume. The amount of planned retention (acc. to present administration division of the country) is shown in Figure 1. Large discrepancy can be observed between particular regions. In general, planned retention should follow largest 


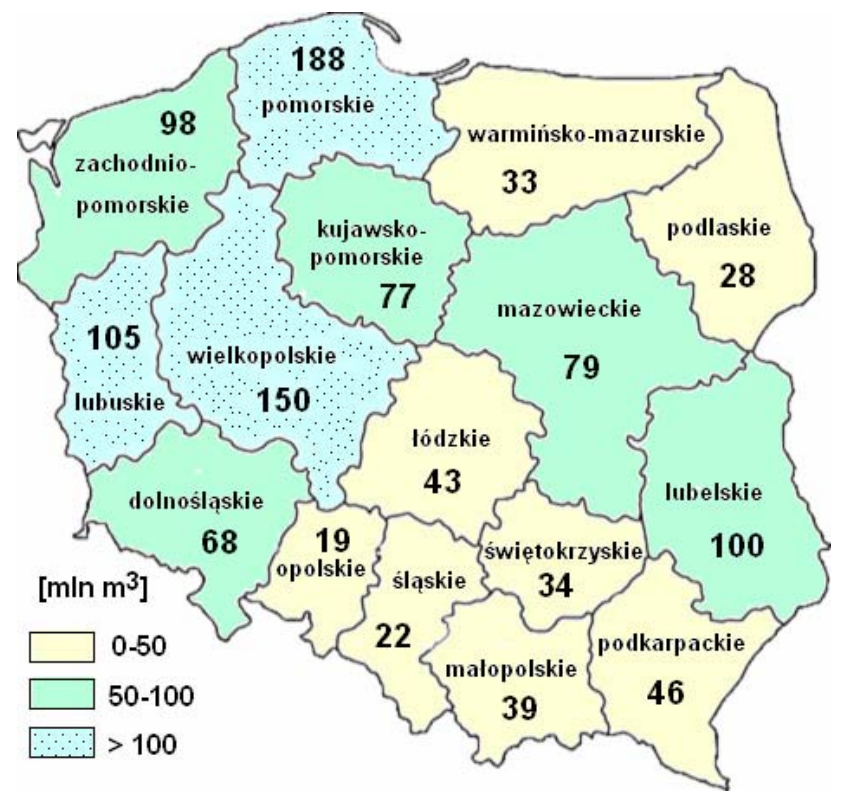

Fig. 1. The increase of retained water volume (million $\mathrm{m}^{3}$ ) planned to the year 2015

needs arising from water deficits [Potrzeby..., 1996], which is in part reflected (Fig. 1) by data for voivodships in the following order: lubelskie, mazowieckie, kujawsko-pomorskie, wielkopolskie and lubuskie. Exceptionally high retention volumes planned for pomorskie voivodship and relatively high - for zachodniopomorskie voivodship result probably from favourable location of small reservoirs along numerous rivers of these voivodships.

Administrative reform performed in 1998 with 16 newly created voivodships hindered practical application of the programmes. Therefore, new programmes based on former locations of objects but considering new conditions (changes in the legal status, climate changes, and possibilities of financial support from EU funds) were later prepared in some voivodships.

\section{ACCOMPLISHMENT OF THE SMALL RETENTION PROGRAMME BETWEEN 1997 AND 2007}

During eleven years 727 small reservoirs were constructed, 4 lakes were dammed, 1551 ponds were built and 672 and 412 constructions were made in basic and detailed reclamation networks, respectively [Wykonanie..., 2007]. The number of most important objects created in particular years is presented in Figure 2. Great differences in the range of project implementation can be seen between years due 

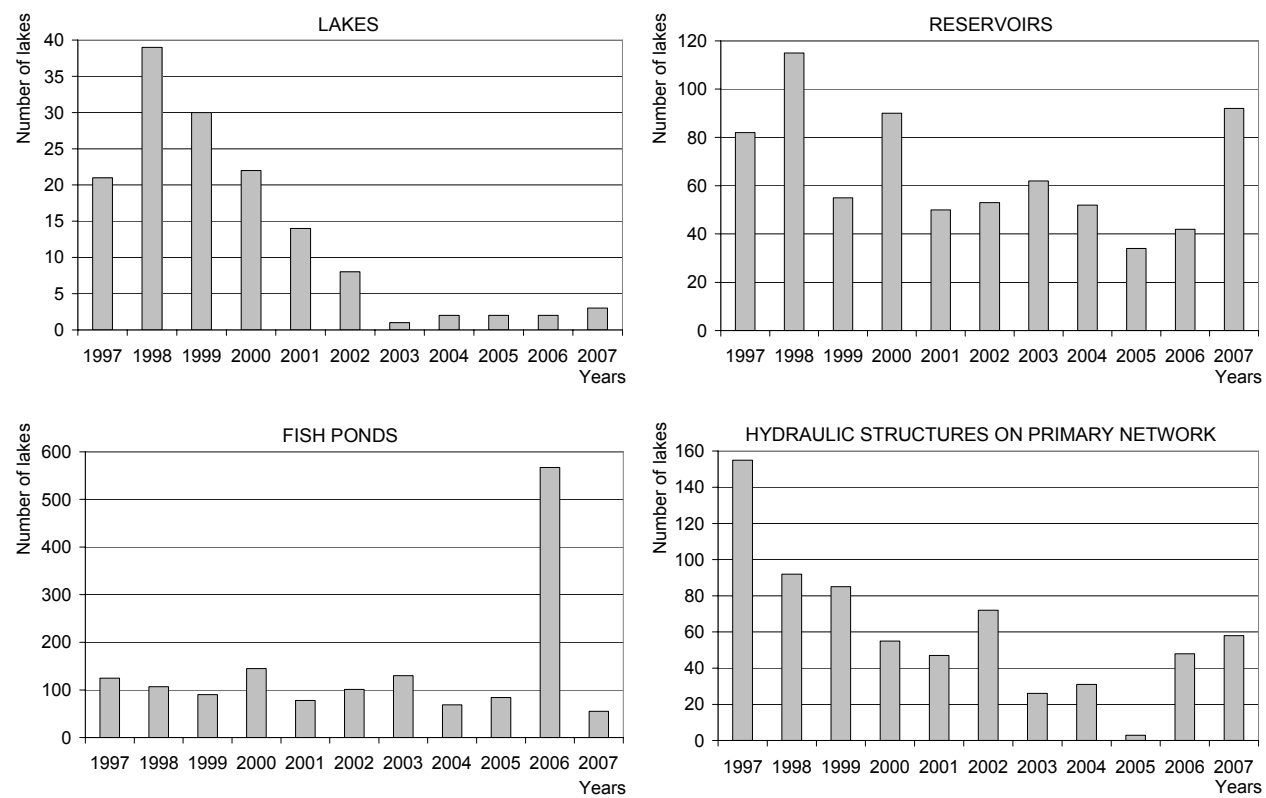

Fig. 2. The number of objects made in the years 1997-2007 within the programme of small retention

mainly to a possibility of gathering funds for investments and to variable advancement of building works initiated before the start of the small retention programme.

The number of objects translates into additional volume of retained water. Volumes obtained in consecutive years for the main elements of small retention are shown in Figure 3.

The largest retention (56.98 million $\mathrm{m}^{3}$ ) was obtained through lake damming, slightly less - in man-made reservoirs $\left(56.18\right.$ million $\left.\mathrm{m}^{3}\right)$. Markedly smaller amounts of water $\left(18.47\right.$ million $\left.\mathrm{m}^{3}\right)$ were collected in fishponds and still less - by lifting water in basic reclamation network $\left(8.30\right.$ million $\left.\mathrm{m}^{3}\right)$ and in other investments $\left(2.14\right.$ million $\left.\mathrm{m}^{3}\right)$.

Eleven years long accomplishment of the programme means over half of the planned period of project completion. The increment of retention capacity obtained in the years 1997-2007 was compared with volumes planned to be achieved to the year 2015. According to presented data, total retention increased in the years 1997 -2007 by 142 million $\mathrm{m}^{3}$. It is only $12.4 \%$ of that planned up to the year 2015 (in the whole country) which makes mean annual increment of c. 13 million $\mathrm{m}^{3}$. These volumes are over 4 times less than the mean planned annual increment of retention volume of 60 million $\mathrm{m}^{3}$. In eleven years only channel retention overcame the planned mean increment of retention volume. Much smaller increment was found in lake damming $(21.7 \%)$ and very small $(8.7 \%)$ in water retention in man-made water reservoirs and ponds (Tab. 1). 

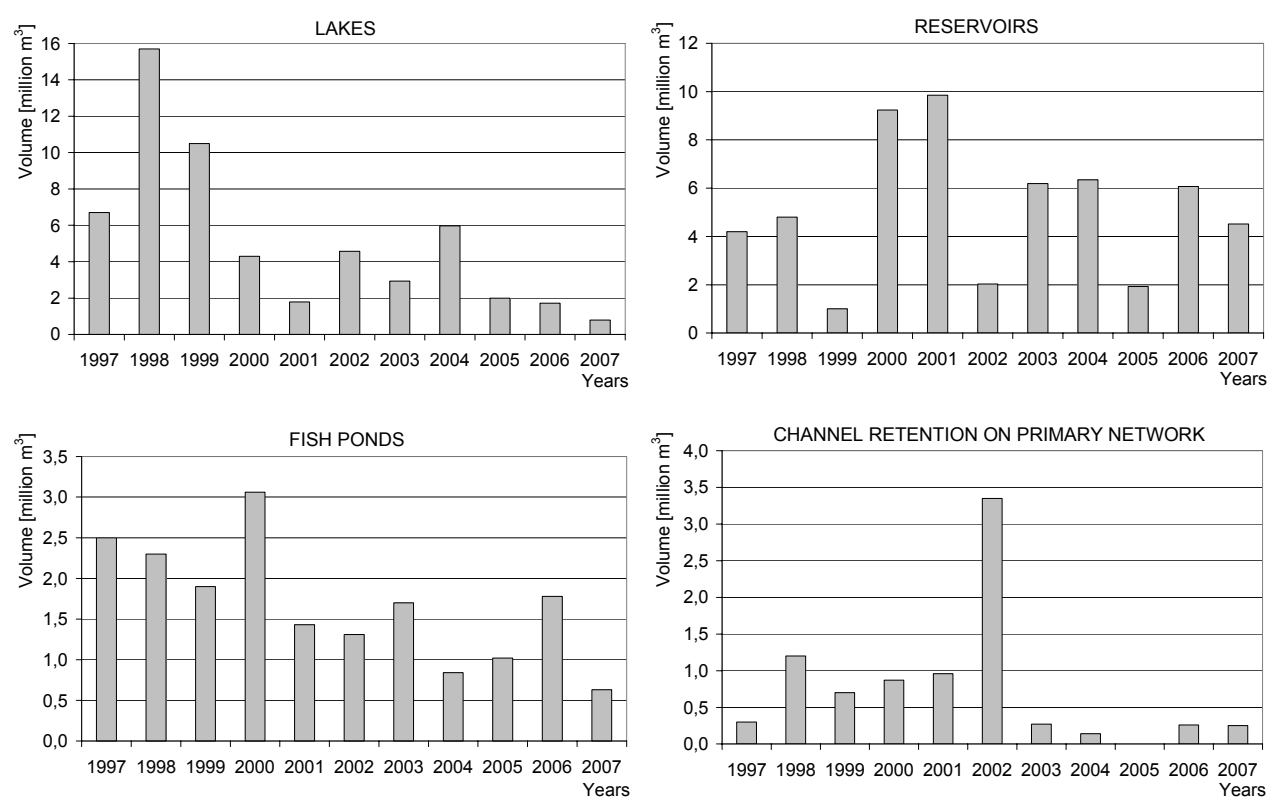

Fig. 3. Total annual volumes of water retained in various objects in the years 1997-2007

Table 1. Comparison of water retention obtained between 1997 and 2007 with volumes planned to be achieved to 2015 in basic objects

\begin{tabular}{|c|c|c|c|}
\hline \multirow[b]{2}{*}{ Object } & \multicolumn{2}{|c|}{ Volumes, million $\mathrm{m}^{3}$} & \multirow{2}{*}{$\begin{array}{l}\text { (b) } \\
\text { (a) } \\
\%\end{array}$} \\
\hline & $\begin{array}{l}\text { planned to } 2015 \\
\text { (a) }\end{array}$ & $\begin{array}{l}\text { obtained in the years } 1997-2007 \\
\text { (b) }\end{array}$ & \\
\hline Dammed lakes & 263 & 57 & 22 \\
\hline Man-made reservoirs and ponds & 860 & 75 & 9 \\
\hline Channel retention & 18 & 10 & 56 \\
\hline Total & 1141 & 142 & \\
\hline Comparable number of years & 19 & 11 & 58 \\
\hline
\end{tabular}

Mean volumes of retained water per one object in a given year were also compared. The values are differentiated for particular elements of small retention (Fig. 4). The largest volumes were obtained when damming lakes. In that case the mean retention increment per lake in the first years (up to 2002) did not exceed 600 thousand $\mathrm{m}^{3}$. In the next two years it was nearly 3 million $\mathrm{m}^{3}$ (damming 1-2 lakes a year) and decreased again in 2007 to slightly more than 260 thousand $\mathrm{m}^{3}$. Mean unit volume of constructed reservoirs was largest in 2001 (almost 200 thousand $\mathrm{m}^{3}$ ). Mean unit volumes in ponds were c. 20 thousand $\mathrm{m}^{3}$ up to the year 2002 and much smaller afterwards. 

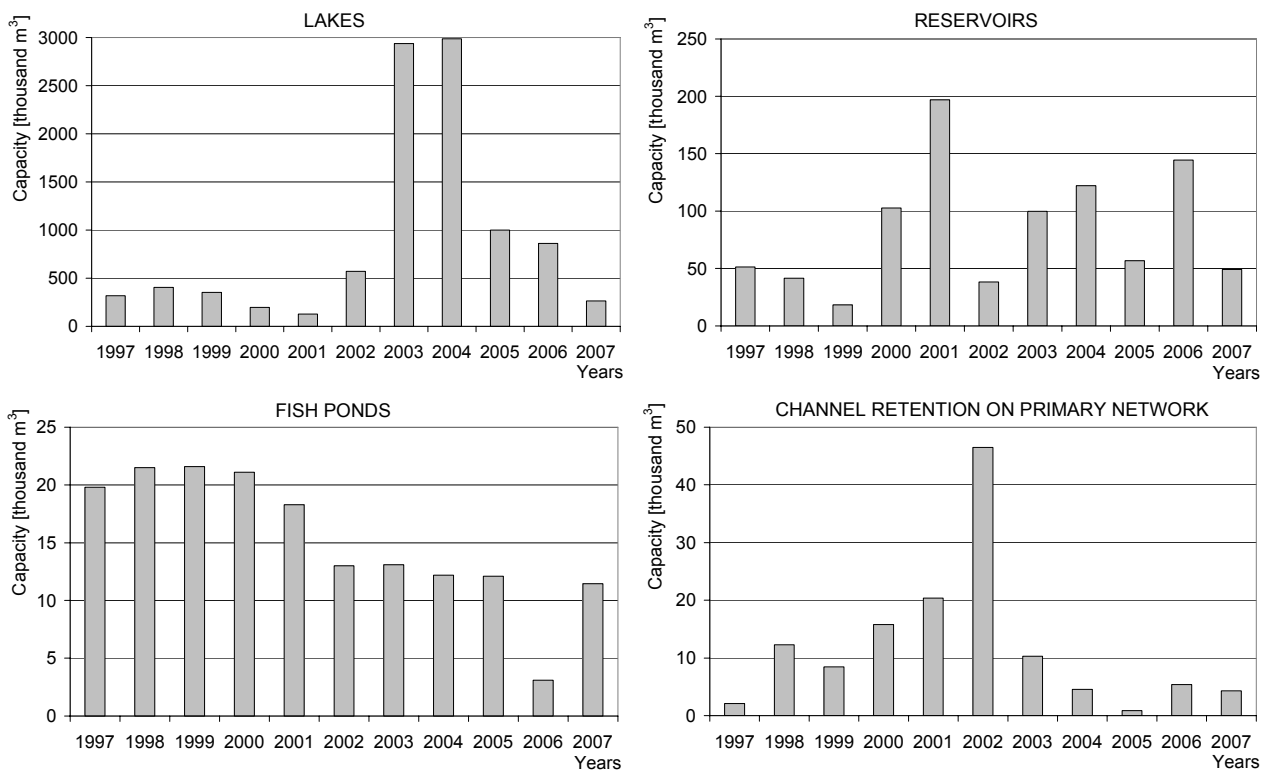

Fig. 4. Mean unit volumes of objects in various forms of water retention accomplished in the years 1997-2007

In channel retention of the basic reclamation network the mean unit volume did not exceed 50 thousand $\mathrm{m}^{3}$ (2002).

Objects of small retention are financed from various sources:

- budget of voivodships,

- voivodship funds for environmental protection and water management,

- National Fund for Environmental Protection and Water Management (NFEPWM),

- budget of communes,

- Fund for the Protection of Agricultural Lands (FPAL),

- Agency for Restructuring and Modernization of Agriculture (ARMA),

- other sources (private funds, forest district offices, anglers associations, mines, foundations, structural funds of the EU).

The share of particular financial sources in the years 1997-2007 is presented in Fig. 5. As can be seen, the largest sums were spent from the budget of voivodships, voivodship funds for environmental protection and water management, and from the so-called other sources. In total 601 million zł were spent in the study period which makes a mean annual expenditure of c. 55 million zł.

The largest means (393 million zł i.e. $65.4 \%$ of the whole costs of small retention) were allocated for the construction of reservoirs, next costly were the water lifting constructions in basic reclamation network - 106 million zł (17.6\%). Detailed partitioning of financial means is given in Figure 6. 


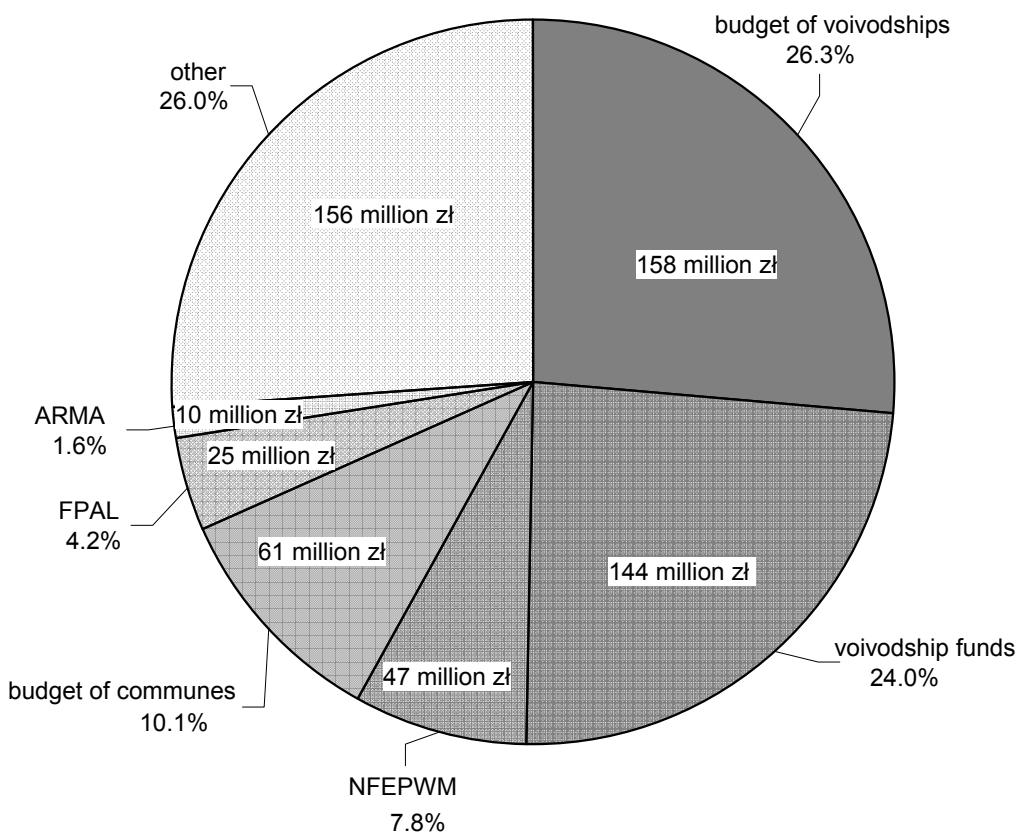

Fig. 5. The share of various sources in financing the small retention programme in the years 1997-2007 (acronyms - see text)

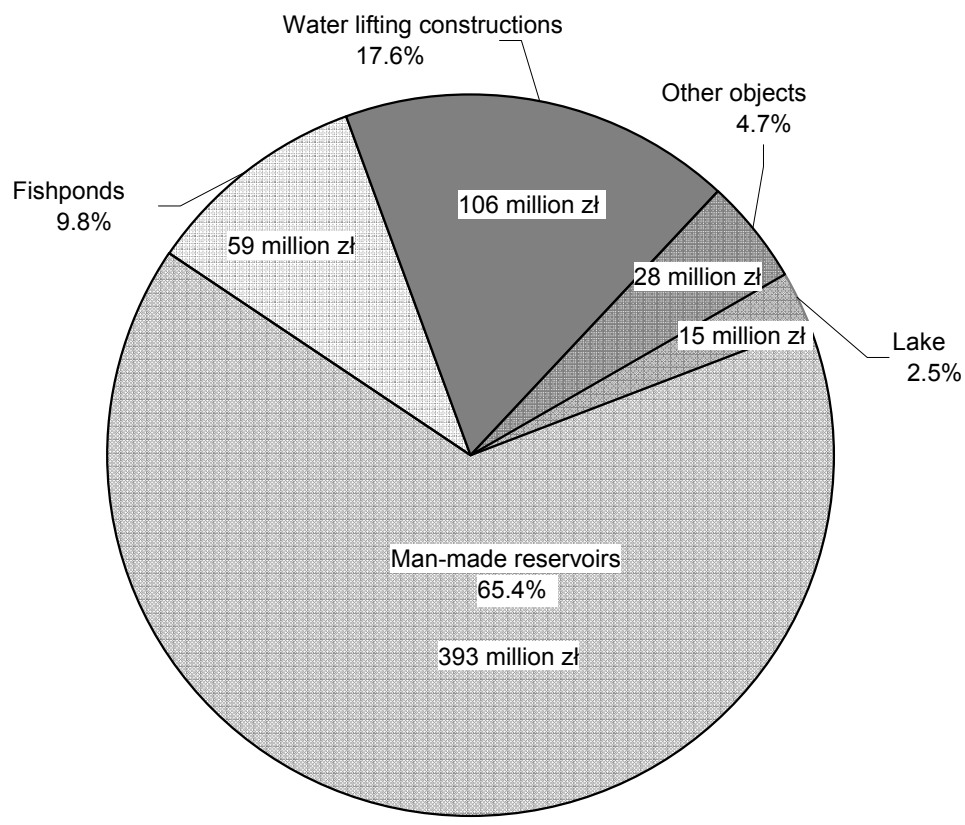

Fig. 6. Structure of investments in objects of small retention in the years 1997-2007 
Unit costs of obtaining $1 \mathrm{~m}^{3}$ of retained water may be a useful index in planning investments associated with small water retention (Fig. 7).
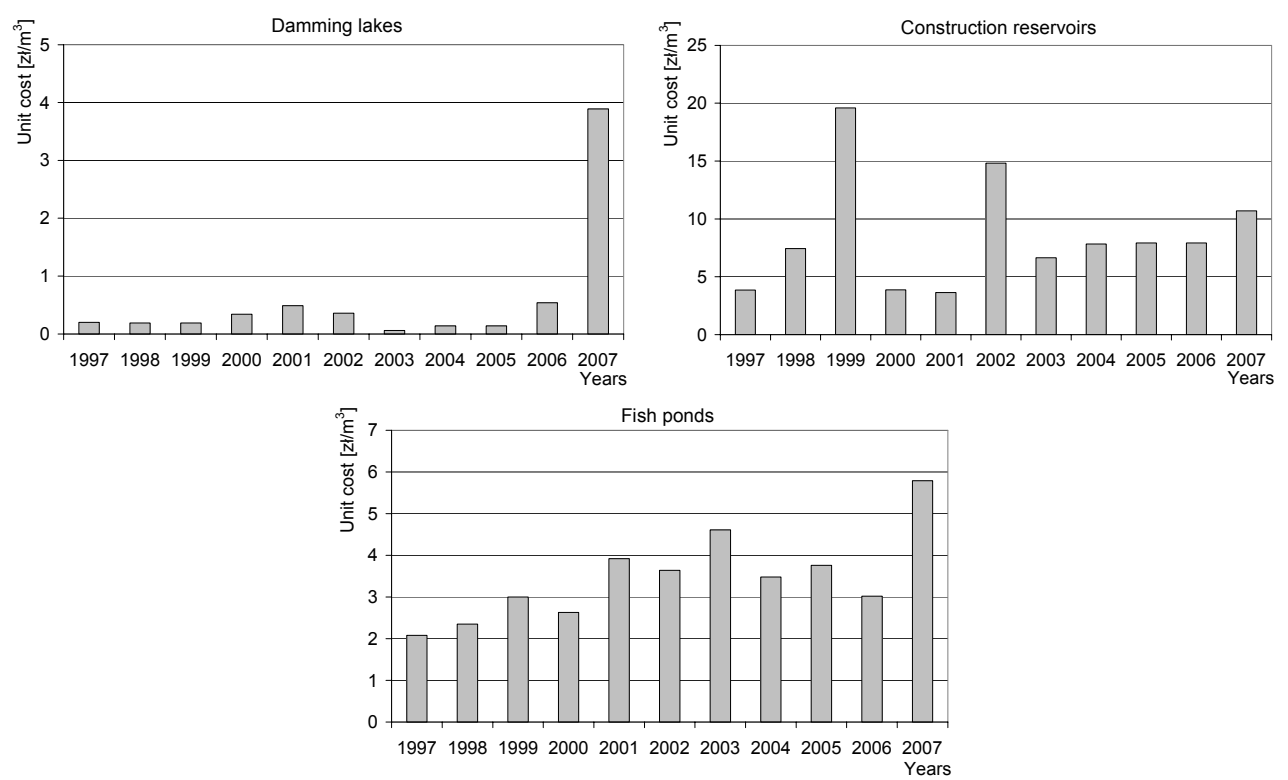

Fig. 7. Mean unit costs of retention increments in successive years of the programme implementation

Up to the year 2006 the most effective $\left(0.06 \mathrm{do} 0.54 \mathrm{z} \cdot \mathrm{m}^{-3}\right)$ method was lake damming. It was a result of relatively low inputs to lake retention (no need to prepare lake basin, small scale of protecting the surrounding areas, even small dam sufficient to lift outflowing water). When the possibilities of increasing lake retention at low costs were exhausted the unit cost of obtaining $1 \mathrm{~m}^{3}$ of retained water markedly increased in 2007 as compared with the previous years. In the case of fishponds the unit cost varied between 2.08 and $5.79 \mathrm{z} \cdot \mathrm{m}^{-3}$. The highest costs were allocated to the construction of artificial reservoirs and varied, depending on the year, from 3.63 to $19.60 \mathrm{z} 1 \cdot \mathrm{m}^{-3}$. It was associated with the location of reservoirs, coverage of the basin, possible purchase of the grounds, size of lifting construction, the need of undertaking some protective measures etc.

As already mentioned (Fig. 1) quite differentiated plans were prepared in various regions of the country. It was also reflected in realisation of the small retention objects in 16 new voivodships (data since 1998 - Table 2).

The largest increments in retention capacity were obtained in wielkopolskie (c. 37 million $\mathrm{m}^{3}$ ) and kujawsko-pomorskie (c. 16 million $\mathrm{m}^{3}$ ) voivodships respectively to the greatest needs for water retention [Potrzeby..., 1996]. 
Table 2. The increment of small water retention in the years 1998-2007 in particular voivodships

\begin{tabular}{l|r|r|r|r|r|r}
\hline \multirow{2}{*}{ Voivodship } & \multicolumn{7}{c}{ Increment of retention volume, thous. m $^{3}$} \\
\cline { 2 - 7 } & $\begin{array}{l}\text { man-made } \\
\text { reservoirs }\end{array}$ & $\begin{array}{c}\text { dammed } \\
\text { lakes }\end{array}$ & fishponds & $\begin{array}{c}\text { water lifting in } \\
\text { reclamation } \\
\text { networks }\end{array}$ & $\begin{array}{c}\text { other } \\
\text { objects }\end{array}$ & total \\
\hline Dolnośląskie & 4948.9 & - & 6858.1 & 18.1 & - & 11825.1 \\
Kujawsko-pomorskie & 323.6 & 11867.1 & 87.4 & 4147.2 & 19.7 & 16445.0 \\
Lubelskie & 6571.8 & 801.0 & 60.2 & 480.8 & & 7913.7 \\
Lubuskie & 143.8 & 2774.1 & 22.1 & 72.0 & 12.5 & 4024.5 \\
Lódzkie & 2380.2 & - & 28.0 & 10.0 & 15.0 & 2433.2 \\
Małopolskie & 11.6 & - & 840.7 & - & - & 852.3 \\
Mazowieckie & 3093.0 & 1500.0 & 222.5 & 622.9 & 7.9 & 5446.5 \\
Opolskie & 62.3 & - & 754.0 & 3.8 & - & 820.1 \\
Podkarpackie & 683.7 & - & 27.6 & 1.5 & - & 712.8 \\
Podlaskie & 844.0 & - & 105.6 & 238.1 & - & 1187.7 \\
Pomorskie & 134.7 & 8426.3 & 14.8 & 46.8 & - & 8622.6 \\
Śląskie & 2302.4 & - & 1418.6 & 6.0 & 4.8 & 3731.8 \\
Śriętokrzyskie & 4229.1 & - & 42.4 & 5.0 & - & 4276.5 \\
Warmińsko-mazurskie & 257.4 & 9477.5 & 1105.5 & 590.2 & 692.0 & 12122.6 \\
Wielkopolskie & 23839.0 & 8237.0 & 2750.9 & 834.0 & 98.5 & 36759.4 \\
Zachodniopomorskie & 12737.2 & 7304.6 & 376.9 & 1638.8 & 385.0 & 10942.5 \\
Total & 52062.7 & 50387.6 & 15715.3 & 8715.9 & 1234.9 & 128116.4 \\
\hline
\end{tabular}

The retention capacity raised slightly less in warmińsko-mazurskie (12.1 million $\left.\mathrm{m}^{3}\right)$, dolnośląskie $\left(11.8\right.$ million $\left.\mathrm{m}^{3}\right)$ and zachodniopomorskie $\left(10.9 \mathrm{~m}^{3}\right)$ voivodships. Obtained increase of retention capacity in the years 1998-2007 is shown in Figure 8 for all voivodships.

Figure 9 presents the percent of obtained rise in water retention in relation to planned increase in particular country regions. The percent varied from $1.5 \%$ in podkarpackie to $36.5 \%$ in warmińsko-mazurskie voivodship. Regions with less than $10 \%$ of project accomplishment prevail in the country. It means that water retention problems are not equally appreciated. Main attention is focussed on large, chiefly flood control, reservoirs. Possibilities of water retention in the reclamation systems are also not fully exploited. At present, these systems contribute in less than $7 \%$ to the structure of water retention increments. Water reclamation facilities (natural streams, channels, ditches) have a total length of 355 thousand km. Hampering outflow from part of these systems, even at water lifting by less than $1 \mathrm{~m}$, affects both surface and groundwater retention. If water retention increases on half of agricultural grounds ( 10 million ha) by only $20 \mathrm{~cm}$, the storage of water in soil would reach c. 2 billion $\mathrm{m}^{3}$ [MIODUSZEWSKI, 1994]. Agriculture is one of the main 


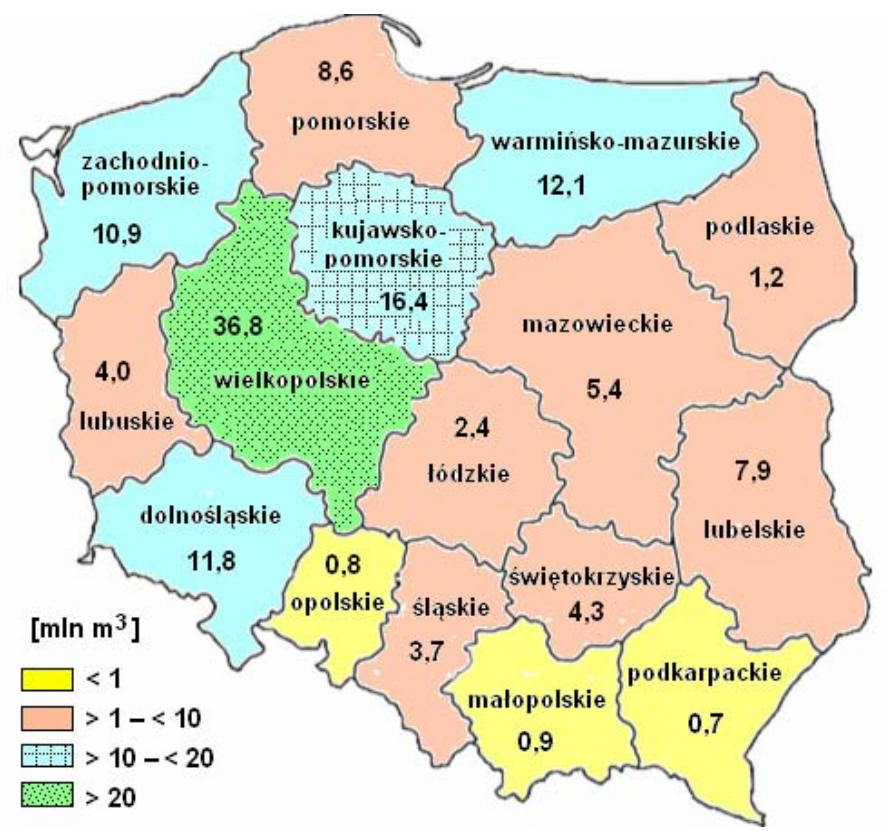

Fig. 8. The increment of water retention (million $\mathrm{m}^{3}$ ) in voivodships in the years 1998-2007

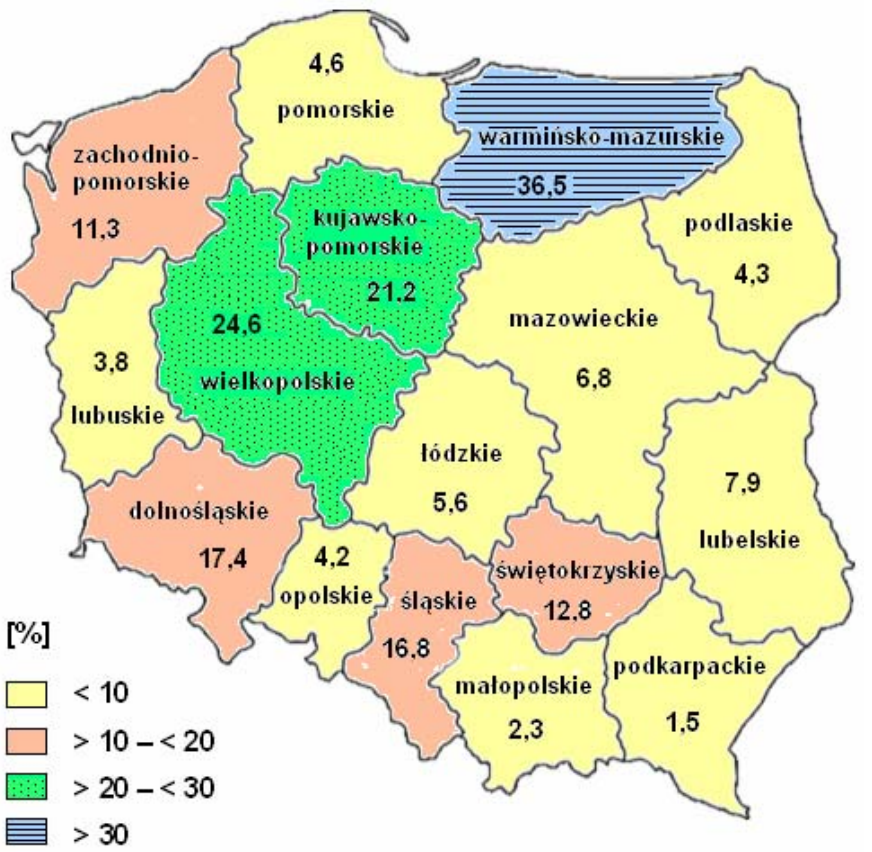

Fig. 9. Obtained increase of retention capacity as percent of the planned 
types of economic activity dependent on water and considered its main consumer [CHEŁMICKI, 2002]. Therefore, droughts that have recently appeared (in the years 2002, 2004, 2005) exert strong impact on yields [ŁABĘDZKI, 2006]. Particularly harmful was the drought in the vegetative season of 2006 when agricultural losses in the country were estimated at 6.1 billion zl. Intensification of actions aimed at complex implementation of small retention would mitigate the effects of droughts in the future. As pointed out by MROZIK and PRZYBYŁA [2007] new chances appear with a possibility of using financial support from European Union.

Apart from the storage of surface waters, small retention objects could be used for recreation, fishery, angling, agriculture and fire control. Relatively small is their role in flood control though the objects might be important in small catchment basins with many reservoirs during summer floods [SZYMCZAK, KOWALEWSKI, 2001]. Immeasurable are the natural and ecological consequences of small retention objects including river restoration, water quality improvement, restriction of hydrogenic soil degradation, and creation of new habitats for waterfowl, amphibians and fish.

\section{CONCLUSIONS}

Presented data on planned and accomplished actions in the scope of small water retention in Poland allow for formulating the following statements and conclusions:

- planned increase of water retention within the programmes of small retention up to the year 2015 involves $1 / 3$ of the country reservoir retention;

- after more than half of the accomplishment period (years 1997-2007) the volume of obtained retention is c. 142 million $\mathrm{m}^{3}$ i.e. slightly more than $12 \%$ of the planned. The main reason is low financial inputs but also complex formal procedures before realisation of an object due to legal restrictions associated mainly with environmental protection;

- up to now (2007) total sum of financial outlays spent on the accomplishment of small retention objects is 601 million zł which makes the mean annual input equal to 55 million zł. Characteristic are in this context the losses in agriculture caused by the drought during vegetative season 2006 estimated at 6.1 billion zt;

- the increase of financial outlays for actions associated with water retention is reasonable since dry periods may occur more often due to climatic changes. Losses caused by these changes largely overcome the costs of realisation;

- attention should be focussed on multiple biological consequences of small water retention. 


\section{REFERENCES}

1. CheŁmicki W., 2002. Woda. Zasoby, degradacja, ochrona. (Water. Resources, degradation, protection). Warszawa, Wydaw. PWN: 306.

2. http://www.gugik.gov.pl/komisja/pliki/polska_mapa_administracyjna_2007.pdf

3. KOWALEWSKI Z., 2003. Wpływ retencjonowania wód powierzchniowych na bilans wodny małych zlewni rolniczych. (The effect of retaining surface waters on water balance in small agricultural catchments). Woda Środ. Obsz. Wiej. Rozpr. nauk. monogr., 6: 126.

4. ŁABĘDZKI L., 2006. Susze rolnicze. Zarys problematyki oraz metody monitorowania i klasyfikacji. (Agricultural droughts. An outline of the problem and methods of monitoring and classification). Woda Środ. Obsz. Wiej. Rozpr. nauk. monogr., 17: 107.

5. MiOdUSZEWSKI W., 1994. Ochrona i kształtowanie zasobów wodnych w małych rolniczych zlewniach rzecznych. Metodyczne podstawy rozwoju małej retencji. (Protection and management of water resources in small agricultural river catchment basins. Methodological basis for the development of small retention). Falenty: Wydaw. IMUZ. Mater. Inf., 25: 35.

6. Mrozik K., PrzybyŁa Cz., 2007. Przestrzenne zróżnicowanie inwestycji małej retencji wodnej w Polsce w latach 1998-2005. (Spatial differentiation of investments in small water retention in Poland in the years 1998-2005).

7. Ochrona środowiska, 2006. Informacje i opracowania statystyczne. (Environmental protection 2006. Information and statistical reports). Warszawa, GUS: 522.

8. Porozumienie z 21.12.1995 r. zawarte między Ministrem Rolnictwa i Gospodarki Żywnościowej a Ministrem Ochrony Środowiska, Zasobów Naturalnych i Leśnictwa dotyczące współpracy w zakresie programu małej retencji. (Agreement of 21.12.1995 between the Minister of Agriculture and Food Industry and the Minister of Environmental Protection, Natural Resources and Forestry on cooperation within the programme of small retention), 1996. Gosp. Wod., 1.

9. Potrzeby i możliwości zwiększenia retencji wodnej na obszarach wiejskich. (Needs and possibilities of increasing water retention in rural areas), 1996. Ed. W. Mioduszewski, E. Kaca. Falenty, Wydaw. IMUZ: 136.

10. SZYMCZAK T., KowAlEWSKi Z., 2001. Impact of reservoir systems on stream outflow in lowland catchment. J. Water Land Dev., 5: 3-14.

11. Wykonanie obiektów małej retencji. Sprawozdania RRW-13. (Accomplishment of the small retention objects. Reports RRW-13). (2000, 2001, 2002, 2003, 2004, 2005, 2006, 2007).

\section{STRESZCZENIE}

\section{Dzialania w zakresie małej retencji podejmowane w Polsce}

Słowa kluczowe: koszty jednostkowe, mała retencja, przyrost retencji, zbiorniki wodne

Program rozwoju małej retencji w Polsce został zapoczątkowany w 1995 r. w wyniku porozumienia pomiędzy resortami rolnictwa i środowiska. Każde ówczesne województwo zostało zobowiązane do opracowania takiego programu na swoim terenie. Realizację działań docelowo przewidziano do $2015 \mathrm{r}$.

Zaplanowano w skali kraju zmagazynowanie w tym czasie w ramach małej retencji ok. $1141 \mathrm{mln} \mathrm{m}^{3}$ wody. Zgodnie $\mathrm{z}$ tym programem zwiększenie objętości 
retencyjnej oparto głównie na małych zbiornikach wodnych (stawach), w których przewidywano uzyskanie retencji rzędu $860 \mathrm{mln} \mathrm{m}^{3}$. Planując podpiętrzanie jezior, zakładano zwiększenie retencji o $263 \mathrm{mln} \mathrm{m}^{3}$, a retencjonując wody na sieci melioracyjnej - $18 \mathrm{mln} \mathrm{m}^{3}$. Przeliczając planowaną wówczas wielkość retencji na województwa w obecnym podziale administracyjnym, największa planowa objętość dotyczy kolejno województw: pomorskiego $\left(188 \mathrm{mln}^{3}\right)$, wielkopolskiego (150 $\left.\mathrm{mln} \mathrm{m}^{3}\right)$ i lubuskiego $\left(105 \mathrm{mln}^{3}\right)$.

Realizację programu rozpoczęto w $1997 \mathrm{r}$. W pracy przedstawiono efekty tych działań, uzyskane do 2007 r., z rozbiciem na poszczególne lata. Dotyczy to liczby obiektów, sumarycznej rocznej objętości retencjonowanej wody w różnych formach jej retencjonowania, średniej jednostkowej pojemności obiektów retencji, średnich kosztów jednostkowych przyrostu retencji w kolejnych latach realizacji programu, źródeł i struktury inwestowania, przyrostów retencji w nowych województwach (lata 1998-2007) oraz stosunku uzyskanej pojemności retencyjnej do retencji planowej w tych województwach.

W pracy wykazano, że po przekroczeniu połowy okresu realizacji programu retencja wyniosła ok. $142 \mathrm{mln} \mathrm{\textrm {m } ^ { 3 }}$, co stanowi nieco 12\% ilości planowej. Do 2007 r. na realizację obiektów małej retencji przeznaczono $601 \mathrm{mln}$ zł, co odpowiada średnim rocznym nakładom ok. $55 \mathrm{mln}$ zł. W tym kontekście znamienne są straty poniesione w rolnictwie na skutek suszy w 2006 r., szacowane na 6,1 mld zł.

W analizowanym okresie największe przyrosty pojemności retencyjnej uzyskano w województwie wielkopolskim (ok. $37 \mathrm{mln} \mathrm{m}^{3}$ ) i kujawsko-pomorskim (ok. $16,5 \mathrm{mln} \mathrm{m}^{3}$ ). Łączna retencja poniżej pojemności $1 \mathrm{mln} \mathrm{m}^{3} \mathrm{w}$ ramach rozpatrywanego programu dotyczy województw podkarpackiego, opolskiego i małopolskiego.

Jest to częściowo zrozumiałe ze względu na budowę w tych rejonach dużych zbiorników retencyjnych.

W pracy zwrócono też uwagę, że nie są wykorzystywane możliwości retencjonowania w systemach melioracyjnych. W strukturze przyrostu retencji dotychczas stanowią one nie całe 7\%, podczas gdy w Polsce urządzenia melioracji wodnych w postaci cieków naturalnych, kanałów i rowów w sumie mają długość 355 tys. km.

Reviewers:

Dr Józef Lipiński

Prof. Czestaw Przybyta 